\title{
Recurrent headache and facial ecchymosis : a case of dermatitis artefacta?
}

Kluger, N.

2020-04

Kluger , N 2020 , ' Recurrent headache and facial ecchymosis : a case of dermatitis artefacta? ' , British Journal of Dermatology , vol. 182 , no. 4 , pp. 1063-1063 . https://doi.org/10.1111/bjd.18691

http://hdl.handle.net/10138/321180

https://doi.org/10.1111/bjd.18691

acceptedVersion

Downloaded from Helda, University of Helsinki institutional repository.

This is an electronic reprint of the original article.

This reprint may differ from the original in pagination and typographic detail.

Please cite the original version. 
DR NICOLAS KLUGER (Orcid ID : 0000-0002-5225-8316)

Article type : Letter to the Editor

\section{Recurrent headache and facial ecchymosis: a case of dermatitis artefacta?}

N. Kluger

Department of dermatology, allergology and venereology, Helsinki University Hospital, Helsinki , Finland

E-mail: nicolas.kluger@hus.fi

Conflict of interest: none declared

Funding: none

Sir,

I read the case recently published as an image gallery in the Journal about a 22 year-old woman, who developed transient and relapsing facial ecchymosis during attacks of trigeminal cephalalgias [1]. As laboratory and imaging were unremarkable, the authors suggested that the cutaneous symptoms "may result from blood extravasation to skin due to trigemino-vascular activation and autonomic vascular dysfunction". Upon examination of the clinical photographic features, the patient displays a striking dark-red, well-delimitated, sometimes linear streak of the right cheek, extending to the neck up to the upper chest. The lesions do not follow traction or Blashko lines. They extend roughly through the trigeminal V2-V3 territories, as well as cervical C3 and $\mathrm{C4}$, and possibly T1 territories. Such geographic presentation is rather evocative of selfinflicted skin lesions [2]. The patient may have applied something on the skin in a desperate

This article has been accepted for publication and undergone full peer review but has not been through the copyediting, typesetting, pagination and proofreading process, which may lead to differences between this version and the Version of Record. Please cite this article as doi: 10.1111/BJD.18691

This article is protected by copyright. All rights reserved 
attempt to alleviate the pain during the painful crises or we are here in a case of cutaneous factitious disorder, as dermatologists happen to see [3].

\section{References}

1. Garcia-Souto F, Lorente-Lavirgen Al, Martinez-Barranca ML, Coronel-Perez IM. Image Gallery: Recurrent headache and facial ecchymosis. Br J Dermatol. 2019; 181:e35.

2. Gieler U, Consoli SG, Tomás-Aragones L, et al. Self-inflicted lesions in dermatology: terminology and classification--a position paper from the European Society for Dermatology and Psychiatry (ESDaP). Acta Derm Venereol. 2013; 93:4-12.

3. Kluger N. Factitious disorders in dermatology: still a challenging diagnosis. Eur J Dermatol. 2017; 27:311-313. 